\title{
Methods of Assessing Cattle Temperament and Factors Affecting it: A review
}

\author{
Jože SMOLINGER ${ }^{1 *}$, Dejan ŠKORJANC ${ }^{2}$ \\ ${ }^{1}$ Chamber of Agriculture and Forestry of Slovenia (CAFS) KGZS, Zavod Ptuj, Ormoška cesta 28, 2250 Ptuj, Slovenia \\ ${ }^{2}$ University of Maribor, Faculty of Agriculture and Life Sciences, Pivola 10, 2311 Hoče, Slovenia
}

\begin{abstract}
In animal husbandry, the herd should consist of animals that are well adapted to a particular environment, which allows a safe working environment and the achievement of optimal production and economic results. Animals react differently to both positive and negative factors of the environment. Individual response to novel situations can affect metabolism as well as various physiological systems. A number of biochemical characteristics can be used as markers for assessing temperament. Temperament can also be defined as a combination of characteristics or qualities that form individual distinctive character. In this review article, we present various methods of assessing cattle temperament, firstly, in environments familiar to the animal, such as the barn and milking parlor, secondly, in unfamiliar special rooms or arenas with special equipment and, thirdly, considering other possible effects on the expression of temperament. Measurement of stress markers in saliva, feces, and hair using noninvasive methods has also been described as one of the approaches to assess temperament. Knowledge of cattle temperament allows us to work safely, introduce appropriate adapted breeding technologies, and improve housing conditions, which, consequently, results in improved animal welfare.
\end{abstract}

Key words: cattle, behavior, temperament, assessment methods

\section{INTRODUCTION}

Temperament is defined as a stable individual trait (Grandin, 1989), and in cattle, can also be defined as the response of animals to human behavior (Burrow, 1997; Ferguson et al., 2008; Cafe et al., 2011). Personality or temperament has also been used in animals to account for individual references in behaviour observed in various challenging situations (Kilgour, 1975). Temperament is a multidimensional trait, and due to its complexity, there is no single objective measurement that could capture all behavioral traits in cattle. Moreover, temperament is most influenced by age, experience, sex, breed, and handling of animals (Brouček et. al., 2013). In practice, the temperament of dairy cows is measured based on tests in barn (Kilgour, 1975; Schwartzkopf-Genswein et al., 1997; Waynert et al., 1999) or on the cows' reactivity during milking commonly (Munksgaard et al., 2001; Rousing et al., 2004). Also, cattle temperament defined as the reactivity of cattle to novel situations, can influence several physiological systems in the body like stress, health and most discovered influence on metabolism (Fordyce et a., 1988). In production, we do not want to have aggressive animals in breeding since they can cause problems in care and endanger the safety of other animals as well as the breeder. Therefore, it is useful to study the temperament of dairy cows both in the barn and in the milking parlor. For this reason, this review is divided into two parts, in which we present various developed tests used in the past studies to assess the temperament of cattle, both in the barn and in the milking parlor. Cattle temperament could also be evaluated based on a cortisol level parameter in hair, saliva, blood or faeces, which was frequently applied/used in published papers. 
The results of various behavioral tests, along with the data on levels of the stress hormone cortisol, are useful for longterm cattle selection. Breeders are aware of the importance of studying cattle temperament and including it in the selection index. A large body of studies has shown a wide range of heredity estimates for temperament (i.e., $h^{2}=0.02$ to 0.70 ), where there may be differences between heredity estimates across different methodologies or breeds (Haskell et al., 2014). Therefore, the question remains whether selection for these traits is justified. Breeders usually exclude problematic animals from their herds, i.e., neurotic heifers and cows. Knowledge about the temperament of different categories of cattle (heifers, bulls, dairy cows) allows developing and planning cattle breeding technologies that have the potential to improve production results and animal welfare but, firstly, we should know how to methodologically evaluate cattle temperament. Therefore, the main aim of this review is to highlight different approaches for assessing cattle temperament.

\section{ASSESSMENT OF TEMPERAMENT IN THE BARN}

The temperament of cattle in the barn can be estimated using different tests such as an open-field test within a specially prepared arena of different sizes (Kilgour, 1975) as well as in the squeeze chute (Schwartzkopf-Genswein et al., 1997; Waynert et al., 1999), and in the so-called arena test (Kilgour et al., 2006; Foris et al., 2018) using a novel object (Boissy and Bouissou (1995) and noise stimuli (Kilgour, 1975). The temperament test takes place not only in the part of the barn where the animals show their active behavior but also in the part of the barn where they rest (Windschnurer et al., 2008; Gibbons et al., 2009).

\section{Open-field test}

The open field test was conducted outdoors and consists of posts and rails with $2 \mathrm{~m}$ corrugated metal walls and overhead tie wires to give the structure rigidity. The walls and overhead wires formed the thirty-six grid squares used for scoring evaluation. The doors were built on every corner (Kilgour, 1975). Author presented an open-field test for assessing the temperament of dairy cows. In the open field test, the animals were tested in a large outdoor open-field arena, and were scored for ambulation, vocalization, elimination, and general behaviour during a $5 \mathrm{~min}$ period for three consecutive days. The advantages of the test were its use of a new environment for assessing the response of animals to such a situation, the simple setup, and the possibility to test several behavioral traits of the animals. The room was enclosed by a $2 \mathrm{~m}$ high corrugated metal fence. The open-field test can be conducted in arenas of varying sizes (Graunke et al., 2013; Foris et al., 2018; Boissy and Bouissou, 1995; MacKay et al., 2013). The open-field test has been upgraded into a version known as the novel object test.

\section{Novel object test}

Boissy and Bouissou (1995) and Kilgour et al. (2006) conducted several different tests to assess temperament, including in response to new objects (Table 1). In these tests, the animal was placed in an arena where novel furnishings had been placed on the floor. The longer the latency to approach a novel object was, the more vocalizations, sniffing the object, and holding the head in an upright position animal performed. In the study of Graunke et al. (2013), 361 calves were assessed. The test was conducted in an open space that was unknown to the calves prior to testing and was divided into four segments. The analysis combined many behavior traits (contact with novel objects, inactivity and activity, exploration, grooming, running, changing arena segment) into a few variables. The authors estimated the influence of sex and weight of animals on all behaviors to describe temperament and correlated these variables to simultaneously measured heart rate variability data.

Heart rate measurement is an alternative measure that has recently been used to evaluate stress responses in dairy cows. Animals that are nervous have an increased heart rate. Heart rate variability is defined as the variation in the length of the time interval between successive heartbeats that are unevenly separated in time (Konold et al., 2011). Interestingly, they did not find any differences in the values between calves of both Charolais and Holstein Friesian breeds. With the exception of Charolais calves running longer than Holstein Friesian calves, there were no differences between breeds in initial data or heart rate baseline measurements. Recently, according to Reenen et al. (2013) and Foris et al. (2018) three tests were presented in arena, i.e., (i) a cow spent 10 minutes alone; (ii) a test with a new setup where an unknown object was dropped from the ceiling and removed after 10 minutes, and (iii) a test where an unknown male in standard clothing entered the arena and stood at a predetermined position in the arena for 10 minutes. Their results confirmed the multidimensional nature of adult dairy cow personality and suggest a relationship between behaviour in individual and in-group situations. The lack of stability in relation to group test scores suggested that companions in the group may have a stronger influence on individual behaviour than expected. The test showed that animals with high cortisol responses to open field test and high avoidance of the novel object at 6 months of age also exhibited enhanced cortisol responses to open field test at 29 months of age (Reenen et al., 2013). On the other hand, Foris et. al. (2018) conducted repeated measurements in the arena test, which showed the stability of most of the individual test parameters after 6 months. Furthermore, based on the repeated measurements of individual behavior in a combined arena test, they identified two personality traits comprising activity/exploration and boldness, underlining the multidimensional nature of personality in cattle.

\section{Avoidance and approach behavior test}

The routine work of animal breeders leads to their interactions with animals. Frequent use of some of these 
routine behaviors (at feeding, cleaning, milking) can cause farm animals to have a great fear of humans (Hemswort et al., 2003). Temperament assessment was carried out by approaching the animals in the test arena by the breeder or a person involved in the study, or by approaching the animals in the feeding place. The avoidance distance of animals in the pen and at the crib (Waiblinger et al., 2003; Windschnurer et al., 2008) (Table 1) was one of the measured characteristic. The behavior of the humans, their interaction with the cows, and the social interactions between the animals in the herd were recorded. Moreover, it was found that avoidance distances in the pen were related to the intensity/quality and continuity of contact with the breeder and to the frequency of friendly interactions between the breeder and the animals. Avoidance distance was lower in animals that had a higher frequency of friendly interactions between breeder and animals. Several authors have examined and evaluated people's attitudes towards cows based on avoidance distance in the pen upon the breeder approaching the cow (Benhajali et al., 2010), avoidance distance in the pen between cows and the breeder and tolerance to tactile interactions (Ebinghaus et al., 2016, 2018), and comparability between observers (Haskell et al., 2014). Positive attitudes towards cows were significantly associated with calmer cows in all test situations (Ebinghaus et al., 2018). However, the variability in estimates for temperament traits that have the same name could very likely be partly explained with differences in measuring protocols, recording methods or breed differences (Haskel et al., 2014).

Windschurer et al. (2008) conducted an approach test in the pen (where the experimenter approached individual animals standing in the feedlot) and an animal approach test for the experimenter in the barn. Results showed a correlation coefficient of over 0.9 between the experimenter for all tests (approach distance at the manger between the experimenter and the cow, rater approach test to the cow, animal touch, and approach distance in the barn between the experimenter and the cow; Table 1). At herd level, the avoidance distance at the feeding place showed consistently high repeatability with coefficients ranging from 0.85 to 0.92 . The correlation coefficients of the avoidance distance in the barn as well as passing and touching lying animals ranged from 0.69 to 0.81 . This means that test results are repeatable when cows are tested twice, even if they are tested and reactions are assessed by different people.

The human avoidance test distance (HAD) test experiment was conducted in the pen by two trained evaluators who were unknown to the animals. Temperament was determined according to the time taken for the animal to leave the pen. Animals were classified as low or high responding (Sutherland et al., 2012a). Shahin (2018) performed an approach test in which the avoidance distance and heart rate of animals was measured (Table 1). He found that avoidance distance significantly decreased after tactile stimulation period for both high and low heart rate cows. Moreover, low and high heart rate cows did not differ in avoidance distances before or after the tactile stimulation. Probst et al. (2012) concluded that the treatment cattle showed significantly less avoidance behavior in the stunning box and cortisol level of the touched animals were lower.

\section{Flight time test}

Temperament can also be assessed with a flight time test. Animals with a faster boxing rate are more active and have a "livelier" temperament. The sex of the cattle can also affect the result. The flight time test is based on the animal being confined in a holding box and then released (Burrow, 1997; Kilgour et al., 2006; Kadel et al., 2006; Mazurek et al., 2011; Schwartzkopf-Genswein et al., 2012; Sebastian et al., 2011). The animal must pass two light bars at a distance of $1.6 \mathrm{~m}$ during the short running distance. The bulls were found to be faster than the heifers in these studies. The flight time test was also performed by Müller and Keyserlongk (2006) and Petherick et al. (2002, 2009), and the measurements were repeated three times over a period of four weeks. It was found that the running speed increased slightly over time (Table 1). Mackay et al. (2013) found that bulls that exhibited high speed were more active in the arena and had a higher average number of steps.

\section{Crush test}

The crush test evaluates the strength of a single animal's response to occlusion. Individual testing of animals was conducted in a squeeze chute (Fordyce et al., 1982; Schwartzkopf-Genswein et al., 1997; Waynert et al., 1999). All bulls were kept in the squeeze chute with their heads in the locking chute. The chute was compressed for $10 \mathrm{~s}$ before the animal was marked. Baseline measurements of applied force during confinement were made on the measuring cells and tension meters. It was found that bulls marked with ice, hot iron, and ice foam showed different response results in the confinement box. A similar test on calves was conducted by Benhajali et al. (2010). A higher average effort, maximum effort, and longer effort duration were measured in bulls that were hot iron tagged. Such tests can now be described as cruel and torturous, as they inflict unnecessary pain on the animals. We believe that such identification and testing of cattle is not necessary to the study of temperament in cattle.

The squeeze chute exit velocity is a test conducted for the purpose of comparing exit velocity measurements in the form of exit score (separately for walk, trot, canter, or run) and flight speed as assessments of cattle temperament. This box can be the starting point for the exit velocity test (initial speed). In this way, temperament can be measured in response to a brief time fixation, such as in the squeeze chute box (Magolski et al., 2013; Vetters et al., 2013). Kilgour et al. (2006) found a little difference in measures of escape and entry in the restraint in a crush, as most animals entered the box without any fixation.

\section{Separation and restraint test}

This test categorizes the different activities that cattle perform when removed from their environment. Animals were separated from their conspecifics (Gutiérrez-Gil et al., 2008; Glenske et al., 2010; Table 1). The test was performed 
in a "home pen" environment with two "accompanying" heifers or cows in the next pen. The group of animals tested was first moved to another fenced area. After a 10-minute habituating period, animals were individually returned to the home enclosure where the responses of the test heifer or cow were recorded with a video system (5-minute test period). The behaviors observed during the test period were classified as walking, running, playing while lying down, kneeling, running away, constant vigilance, occupancy and interaction with parts of the enclosure, or the occurrence of events such as vocalization, urination, and defecation. The results showed that heifers or cows generally spent more time in active states (e.g., walking, running) than at rest. A similar experiment where cows were kept in a containment barrier was conducted by Stephansen et al. (2018). In the test, the classifier or farmer must move the cow into a cubicle and classify handling temperament. They found that the farmerassessed heritability for handling temperament is little higher than for farmer-rated temperament $\left(h^{2}=0.11, h^{2}=0.10\right.$, respectively). In cattle breeding and temperament assessment it is important to use an accurate scale of temperament assessments and the space where the test can be performed. A scale (1-9) was used to evaluate temperament. The area of the enclosure varied between $30 \mathrm{~m}^{2}$ (Müller et al., 2006) and $54 \mathrm{~m}^{2}$ (Kilgour et al., 2006). To score handling temperament, it is preferred that the cow is restrained in headlock barriers. The test compared the ratings of farmers with those of experienced classifiers. In an experiment, they found that handling temperament is heritable and that the $\mathrm{h}^{2}$ is similar to farmer-assessed temperament $(0.13)$.

\section{Noise stimuli}

The test for noise pollution is probably done because the animals graze near airports or other noisy facilities. It is necessary to determine how cows react to noise and how they may adapt to such conditions. Noise stimuli used during heifer and cow temperament tests were recorded in advance, before the test, two speaker clusters, used to simulate the jet fly-over conditions, were supported along the center line of the holding area about $2 \mathrm{~m}$ above the cows' heads. Head et al. (1993) performed a noise test on cows prior to milking. Cows were exposed to a series of high-intensity sounds with pure tone components, such as pumps, electric motors, and broadband noise sources. It was found that the response of dairy cows to jet aircraft noise before milking was barely perceptible. Waynert et al. (1999) used different sounds (Table 1), and one of the recordings contained the sounds of two men shouting to encourage the cattle to move. The second recording consisted of sounds emanating from a lock box (the closing of a metal door), the sound of metal on metal, and the simulated sounds of cattle moving within an enclosure. In areas where metal might meet metal, a coating was applied to the lock box to reduce extraneous noises unrelated to processing. It was found that heifers exposed to the noise test generally had a higher heart rate during the 1 -minute test period than heifers in the noise-free group.

\section{Temperament of cows at milking}

The temperament of dairy cows in response to routine handling during milking has been estimated (Dickson et al., 1970). Temperament in the milking parlor can also be evaluated as the cow's response to humans, the specific cow's behavior during milking, and the influence of location and position during milking on animal behavior (Fahim et al., 2018).

\section{Stepping and kicking behavior during milking}

By stepping and kicking cows in the milking parlor, they show a certain temperament that can lead to injury to the animals or lower milk production. In one study, the behavioral test during milking was performed 3-4 times in the milking parlor (Table 2) and the number of kicks and step overs were recorded. The authors found that on farms with lower milk yield, cows showed a lower approach (dwell time within $3 \mathrm{~m}$ of the herdsman) to the herdsman (Breuer et. al., 2000).

Munksgaard et al. (2001) investigated the relationships between kicking during milking and the response to human approach in free-ranging animals (Table 2). They found that $14 \%$ of cows kicked once during milking, and $3 \%$ of cows kicked repeatedly during milking. Cows characterized by a daily milk yield of less than 20 liters were more likely to kick during milking. On the other hand, Rousing et al. (2004) studied the relationships between cows kicking and stepping during milking and the response to humans. They found that stepping during milking was positively associated with its avoidance behavior to the estimator. Moreover, cows with damaged teats were also more likely to step during milking.

\section{Reactivity at milking and its relation to milk production}

Szentléleki et al. (2015) studied the relationships between temperament during milking and milk production characteristics. The observation of cows in the milking parlor was conducted every month throughout the year. Temperament during milking was assessed by direct observation on a 5-point scale (1-very nervous, 5-very calm). Significant differences were found between primiparous and older cows in terms of udder cleaning behavior. The older cows had higher estimated temperament ratings and/or were calmer in comparison to primiparous. Dutt et al. (2016) reported that no significant effects of cow temperament at milking on their production and reproductive characteristics. Fahim et al. (2018) studied the advantages of milking on the same side of the milking parlor. Dairy cows were more nervous and milk flow was slower in animals if cows were on the unfamiliar side of the milking parlor. 
Table 1: Overview of different methods for assessing temperament

\begin{tabular}{|c|c|c|}
\hline Test & Basic measurements & Authors \\
\hline $\begin{array}{l}\text { Open- } \\
\text { field test }\end{array}$ & $\begin{array}{l}\text { The behavioral test was conducted in an open room of } 38 \mathrm{~m}^{2} \text { unknown to the calves } \\
\text { before the test. Some authors used other dimensions of the room for the test, an arena } \\
\text { of } 25 \mathrm{~m}^{2} \text {, where microphones were installed and a CCTC camera was attached under } \\
\text { the roof, which provided a good view of the entire arena, which was divided into four } \\
\text { segments of } 9.6 \mathrm{~m}^{2} \text {. }\end{array}$ & $\begin{array}{l}\text { Boissy et al. (1995), } \\
\text { Kilgour et al. (1975, } \\
\text { 2006), Graunke et al. } \\
\text { (2013), MacKay et al. } \\
\text { (2013, 2014), Reenen } \\
\text { et al. (2013), Foris et al. } \\
(2018)\end{array}$ \\
\hline $\begin{array}{l}\text { Novel } \\
\text { object test }\end{array}$ & $\begin{array}{l}\text { After the test animal was allowed to habituate outdoors for } 10 \text { minutes, a test was } \\
\text { conducted with a } 0.5 \mathrm{~m} \text { high traffic cone as the new object. Behavior was recorded } \\
\text { live using the observer's "Tollbooth" monitoring software. The remaining tests were } \\
\text { performed by three more experienced observers for assessment of } 10 \text { different } \\
\text { behaviors (contact with a new object, inactivity, exploration, preening, activity, } \\
\text { walking, vocalization, room change, prolonged time in the room where the new } \\
\text { object is placed, and staying next to the room where the new object is). }\end{array}$ & $\begin{array}{l}\text { Boissy et al. (1995), } \\
\text { Gibbons et al. (2009), } \\
\text { Kilgour et al. (1975, } \\
\text { 2006), Graunke et al. } \\
\text { (2013), MacKay et al. } \\
\text { (2013, 2014), Reenen } \\
\text { et al. (2013), Foris et al. } \\
\text { (2018) }\end{array}$ \\
\hline $\begin{array}{l}\text { Avoidance } \\
\text { and } \\
\text { approach } \\
\text { behavior } \\
\text { test }\end{array}$ & 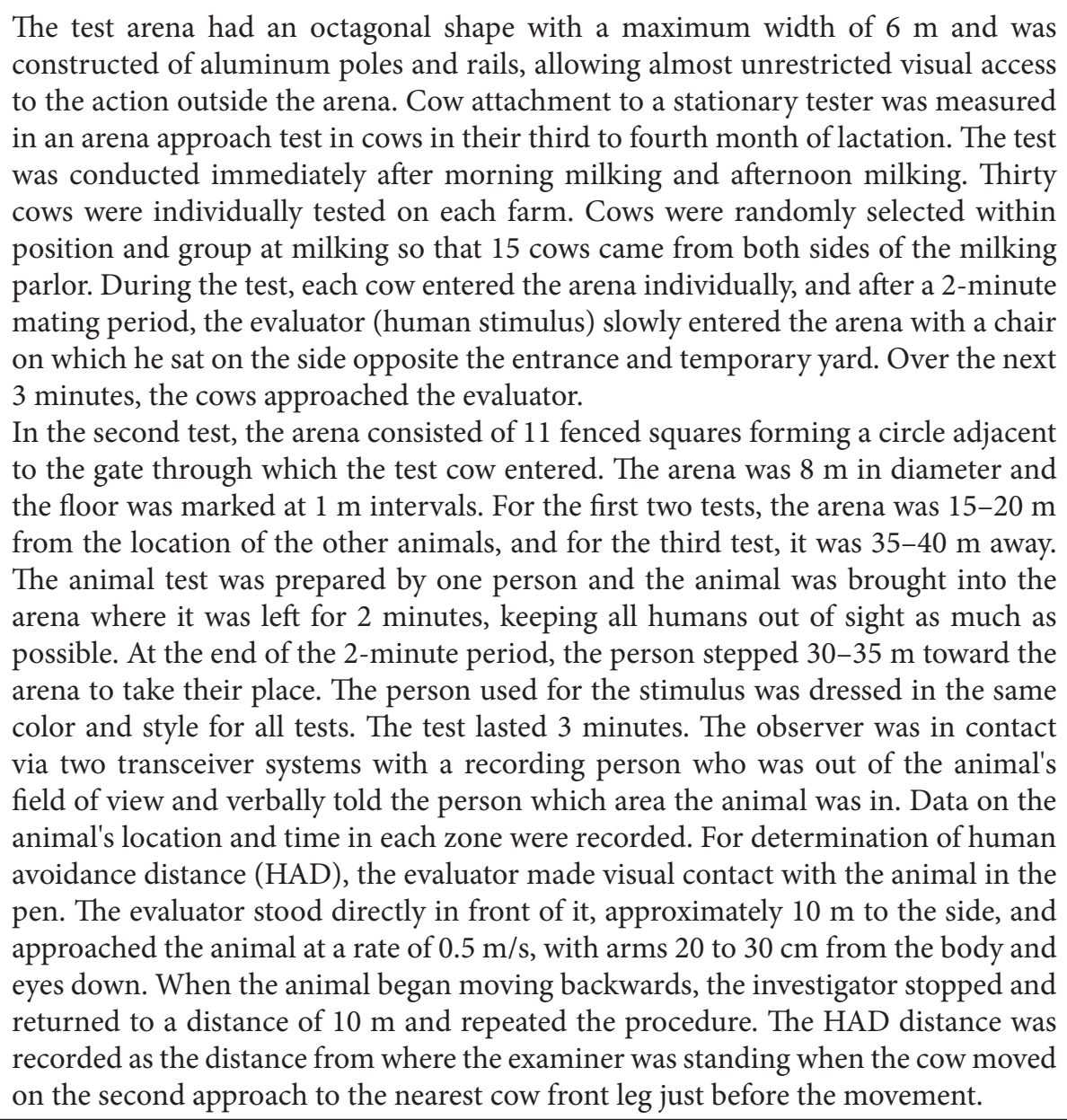 & $\begin{array}{l}\text { Hemsworth (2003), } \\
\text { Petherick et al. (2009), } \\
\text { Müller et al. (2006), } \\
\text { Windschurer et al. } \\
\text { (2008), Sutherland et al. } \\
\text { (2012a), Haskell et al. } \\
\text { (2014), Ebinghaus et al. } \\
\text { (2016, 2018), Shanin et } \\
\text { al. (2018). }\end{array}$ \\
\hline $\begin{array}{l}\text { Flight } \\
\text { time test }\end{array}$ & $\begin{array}{l}\text { The flight time test is performed at the exit of the animal weighing box. The first box } \\
\text { was } 1.5 \mathrm{~m} \text { from the exit of the weighing box, and the boxes were approximately } 2.6 \\
\mathrm{~m} \text { apart ( } 2.5 \text { to } 2.9 \mathrm{~m} \text { ). After the animal was released from the box, it moved forward } \\
\text { across the room and passed the first light beam, triggering the timer. When the } \\
\text { animal crossed the second light beam, the meter stopped and displayed the time it } \\
\text { took the animal to cross } 2.6 \mathrm{~m} \text {. The timer was then triggered. The second experiment } \\
\text { was conducted in an enclosed area. The raceway was } 20 \mathrm{~m} \text { long and } 1.2 \mathrm{~m} \text { wide. The } \\
\text { beam was at a height of } 0.9 \mathrm{~m} \text { above ground. The first laser was located at a distance } \\
\text { of } 5.4 \mathrm{~m} \text { from the box and the second } 1.2 \mathrm{~m} \text { behind it. }\end{array}$ & $\begin{array}{l}\text { Burrow (1997), Kilgour } \\
\text { et al. (2006), Kadel et al. } \\
\text { (2006), Petherick et al. } \\
\text { (2002, 2009), Müller et } \\
\text { al. (2006), Gibbons et al. } \\
\text { (2011), Sebastian et al. } \\
\text { (2011), Mazurek et al. } \\
\text { (2011), Schwartzkopf- } \\
\text { Genswein et al. (2012), } \\
\text { Mackay et al. (2013), } \\
\text { Haskell et al. (2014) }\end{array}$ \\
\hline
\end{tabular}




\begin{tabular}{|c|c|c|}
\hline Crush test & $\begin{array}{l}\text { Motion was measured with an electronic motion detector that has an independent } \\
\text { power source. Analog voltage changes that occur when an animal moves on a scale } \\
\text { are digitally sampled at a rate of } 122 \text { times over a one-minute period. } \\
\text { A pair of head-mounted girth gages measured the force exerted by the animal during } \\
\text { a head impact at neck closure. Output signals were measured in millivolts }(\mathrm{mV}) \text {. The } \\
\text { voltmeters were connected to a data logger that digitized and temporarily stored the } \\
\text { data. The data logger was programmed to sample the voltage in the measurement } \\
\text { circuit } 20 \text { times per second. The computer retrieved these data from the data } \\
\text { logger and stored them as a data file. The variables in the file that were of interest } \\
\text { were the sampling time and the analog voltages. The mean, minimum, maximum, } \\
\text { standard deviation (SD), and absolute strain force were calculated for each animal. } \\
\text { The displacement of the measurement force was recorded as the number of passes } \\
\text { (strokes). The type of exit from the restraint box was subjectively assigned to each } \\
\text { animal; the original scale for this measurement was } 1=\text { walk, } 2=\text { trot, } 3=\text { run, and } \\
4=\text { jump. }\end{array}$ & $\begin{array}{l}\text { Fordyce et al. (1982), } \\
\text { Waynert et al. (1999), } \\
\text { Kilgour et al. (2006), } \\
\text { Benhajali et al. (2010), } \\
\text { Schwartzkopf-Genswein } \\
\text { et al. (2012), Black et al. } \\
\text { (2013), Magolski et al. } \\
\text { (2013) }\end{array}$ \\
\hline $\begin{array}{l}\text { Separation } \\
\text { and } \\
\text { restraint } \\
\text { test }\end{array}$ & $\begin{array}{l}\text { Animals were observed in groups of } 10 \text {, the room was } 100 \mathrm{~m}^{2} \text { and the smaller room } \\
\text { was } 25 \mathrm{~m}^{2} \text {. Some authors reported different room sizes }\left(30 \text { and } 54 \mathrm{~m}^{2}\right) \text {. Both rooms } \\
\text { were separated by a door. The evaluator separated the single animal into a smaller } \\
\text { room. The room size was } 25 \mathrm{~m}^{2} \text {, and the animal was alone in the waiting area for } \\
30 \mathrm{~s} \text {. The evaluator entered the waiting area and remained quiet for another } 30 \mathrm{~s} \text {. } \\
\text { The animal was then left alone in the waiting area. The evaluator then attempted } \\
\text { to move the animal to a } 4 \mathrm{~m}^{2} \text { room over a } 120 \mathrm{~s} \text { period. In cases where this was } \\
\text { successful, the evaluator attempted to pat the animal on the back for a maximum of } \\
30 \mathrm{~s} \text {. The animal was then moved to a room of other animals and then moved to a } \\
\text { different size room. Then, the animal was moved to a } 4 \mathrm{~m}^{2} \text { room. In the separation } \\
\text { test, the animal's responses (walking, running, playing, lying down, kneeling, fleeing, } \\
\text { constant vigilance, occupancy, and interaction with equipment) and when separated } \\
\text { from conspecifics (cows, calves) were measured. }\end{array}$ & $\begin{array}{l}\text { Kilgour et al. (2006), } \\
\text { Gutiérrez-Gil et al. } \\
\text { (2008), Glenske et al. } \\
\text { (2010), Vetters et al. } \\
\text { (2013), Black et al. } \\
(2013)\end{array}$ \\
\hline $\begin{array}{l}\text { Noise } \\
\text { stimuli }\end{array}$ & $\begin{array}{l}\text { The noise stimuli used during the tests were recorded in advance. Sounds commonly } \\
\text { heard when handling cows were recorded. One of the recordings contained the } \\
\text { sounds of two men shouting to encourage the cattle to move, and the other recording } \\
\text { consisted of sounds coming from a cattle lock box. These two recordings were edited } \\
\text { together into a single length of } 1 \text { minute. The sound of a jet aircraft was also used. }\end{array}$ & $\begin{array}{l}\text { Head et al. (1993), } \\
\text { Waynert et al. (1999) }\end{array}$ \\
\hline
\end{tabular}

Table 2: Overview of the different methods for assessing temperament in the milking parlor

\begin{tabular}{|c|c|c|}
\hline Test & Basic measurements & Authors \\
\hline $\begin{array}{l}\text { Temperament } \\
\text { of cows in } \\
\text { milking } \\
\text { parlor }\end{array}$ & $\begin{array}{l}\text { Assessments were made for three morning milkings in the first, second, } \\
\text { and third months of lactation. Each cow was handled by two different } \\
\text { handlers, one treating the cow gently (kindly) and the other roughly. } \\
\text { In the presence of a milker, the phenomena of crossing and kicking were } \\
\text { recorded. }\end{array}$ & $\begin{array}{l}\text { Breuer et al. (2000), } \\
\text { Munksgaard et al. } \\
\text { (2001), Rousing et al. } \\
\text { (2004) }\end{array}$ \\
\hline $\begin{array}{l}\text { Stepping } \\
\text { and kicking } \\
\text { behavior } \\
\text { during } \\
\text { milking }\end{array}$ & $\begin{array}{l}\text { Milking temperament was assessed by direct observation of the investigators on } \\
\text { a } 5 \text {-point scale ( } 1=\text { very nervous, } 2=\text { constantly and vigorously trampling, no } \\
\text { kicking, } 3=\text { occasional strong leg movements, } 4=\text { standing quietly with a few slight } \\
\text { leg movements, } 5=\text { very quiet }) \text { always during udder preparation and milking. Cow } \\
\text { temperament was scored between morning and evening milking. Scale: } 1=\text { very } \\
\text { nervous; } 2=\text { nervous; } 3=\text { average; } 4=\text { calm; } 5=\text { very calm. }\end{array}$ & $\begin{array}{l}\text { Sewalem et al. (2011), } \\
\text { Szentléleki et al. (2015), } \\
\text { Dutt et al. (2016), Fahim } \\
\text { et al. (2018) }\end{array}$ \\
\hline $\begin{array}{l}\text { Reactivity at } \\
\text { milking and } \\
\text { its relation } \\
\text { to milk } \\
\text { production }\end{array}$ & $\begin{array}{l}1=\text { cow standing still; } 2 \text { = cows showing some slight movements with one or both } \\
\text { hind legs; } 3 \text { = cows showing lively movements with one or both hind legs; } 4=\text { cow } \\
\text { showing constant vigorous movements of hind legs, or handler ties hind legs. }\end{array}$ & $\begin{array}{l}\text { Reenen et al. (2002), } \\
\text { Sewalem et al. (2002), } \\
\text { Sutherland et al. } \\
\text { (2012b), Szentléleki et } \\
\text { al. (2015), Dutt et al. } \\
\text { (2016), Carlström et } \\
\text { al. (2016), Carvalhal et } \\
\text { al. (2017), Bharti and } \\
\text { Kamboi (2019), Wethal } \\
\text { and Heringstadt (2019) }\end{array}$ \\
\hline
\end{tabular}


Table 3: Assessment of temperament by analysis of hormones, glucose, and insulin

\begin{tabular}{|c|c|c|}
\hline Test & Basic measurements & Authors \\
\hline $\begin{array}{l}\text { Determination } \\
\text { of cortisol } \\
\text { from hair }\end{array}$ & $\begin{array}{l}\text { Serum cortisol concentrations were determined using a commercially available } \\
\text { set of enzyme immunoassays. Two pigmented hair samples were collected from } \\
\text { each cow each month, for a total of } 12 \text { months, and additional samples were } \\
\text { collected from various sites on the body. The average cortisol concentration } \\
\text { in the hair was compared to the average concentration in the other months (a } \\
\text { comparison was also made during the seasons). Current reproductive status } \\
\text { was recorded for each hair sample. White hair samples were collected from the } \\
\text { forehead during morning milking. In the second experiment, hair samples were } \\
\text { collected on the same day. In the third experiment, the hairs were collected } \\
\text { one hour before laying the food at noon. Hair samples were collected from the } \\
\text { tails of } 37 \text { lactating cows ( } 18 \text { in their first lactation and } 19 \text { in second or more } \\
\text { lactations). }\end{array}$ & $\begin{array}{l}\text { Burdick-Sanchez et } \\
\text { al. (2016), Curley et } \\
\text { al. (2008), Burnett et } \\
\text { al. }(2014) \text {, Braun et al. } \\
(2017,2019) \text {, Uetake } \\
\text { et al. }(2018) \text {, Perič et } \\
\text { al. (2017), Parra et al. } \\
\text { (2018), Nejad et al. } \\
(2019)\end{array}$ \\
\hline $\begin{array}{l}\text { Analysis of } \\
\text { fecal samples } \\
\text { for cortisol }\end{array}$ & $\begin{array}{l}\text { Fecal samples were collected for analysis of cortisol metabolites (twice daily, } \\
\text { morning and evening). Samples were stored on ice and frozen. }\end{array}$ & Jurkovich et al. (2017) \\
\hline $\begin{array}{l}\text { Determination } \\
\text { of glucose } \\
\text { tolerance } \\
\text { and insulin } \\
\text { sensitivity }\end{array}$ & $\begin{array}{l}\text { Blood glucose concentrations were determined by the modification of the } \\
\text { enzyme autokit. Insulin concentrations were determined by ELISA. }\end{array}$ & $\begin{array}{l}\text { Curley et al. (2008), } \\
\text { Burdick-Sanchez et al. } \\
\text { (2016) }\end{array}$ \\
\hline
\end{tabular}

\section{ASSESSMENT OF TEMPERAMENT BASED ON CORTISOL, GLUCOSE TOLERANCE, AND INSULIN SENSITIVITY}

Cortisol is an important mediator of the stress response in animals, which is triggered by activation of the hypothalamic-pituitary-adrenal (HPA) axis during a stressful event. Activation of the HPA axis can produce a range of physiological changes during acute stressful events (i.e., short-term or small increases in cortisol) and stimulates a shift of resources toward adaptive functions such as arousal, alertness, and increased oxygenation and nutrition of the brain, heart, and skeletal muscles. A large body of literature has described the importance of cortisol levels as a marker for determining the stress situation in animals. Cortisol can be analyzed from a variety of media and is analyzed primarily from blood; however, this is invasive, and more recent methods use a non-invasive approach to detect this marker in hair, saliva, and feces (Burnett et al., 2014). Therefore, cortisol levels could be used in practice as a noninvasive method with additional information for determining the temperament of cattle.

\section{Determination of cortisol from hair}

Hair cortisol analysis is a complementary means of monitoring the HPA axis because it reflects cortisol secretion over time. The HPA axis regulates the stress response. When stress is perceived, corticotropin-releasing hormone is released by the hypothalamus, which travels via the portal circulation to the pituitary gland, where it triggers the secretion of adrenocorticotropic hormone, which in turn triggers the secretion of glucocorticoid hormones in the adrenal cortex (mainly in the zona fasciculata). The two main glucocorticoid hormones are cortisol and corticosterone, which are very similar in chemical structure but have different importance in different animal species. Thus, in laboratory animals (mice, rats) the major glucocorticoid is corticosterone, whereas in humans and most domestic animals, including cattle, the major glucocorticoid is cortisol (Brown, 1994). Determination of cortisol from hair has been shown to be a reliable alternative to blood for measuring chronic stress. Burnett et al. (2014) examined the effects of hair color, collection site, and treatment mode on cortisol concentrations in hair from lactating black and white Holstein cows (Table 3). They found that in black and white cows, hair located at the tip of the tail is always white, grows faster than on other parts of the body, and is sensitive enough to detect cortisol changes corresponding to intervals of less than 3 weeks. Braun et al. $(2017,2019)$ determined cortisol concentrations in hair grown one month after shearing and in hair from a previously uncut area and examined the effects of season, pregnancy, and disease on cortisol concentrations in hair from dairy cows. They found that the effect of shortterm stressors on cortisol levels was easier to detect in hair grown for a month than in hair from a previously uncut area.

The second experiment examined whether calves bred according to improved animal welfare standards experienced less stress than calves bred under a conventional system that met the minimum standards of Swiss animal welfare legislation and whether this difference was reflected in differences in hair cortisol concentrations. It was found that the mean hair cortisol concentrations in both product groups were 2.4 and $2.3 \mathrm{pg} / \mathrm{mg}$ of hair. Moreover, cortisol levels in the adrenal cortex $(1.7$ and $1.6 \mu \mathrm{g} / \mathrm{g})$, total adrenal cortisol 
(4.8 and $4.7 \mu \mathrm{g})$, cortex weight (3.2 and $3.1 \mathrm{~g}$ ), medulla weight (1.7 and $1.7 \mathrm{~g}$ ), and lobe thickness (1430 and 1532 $\mu \mathrm{m})$ did not differ significantly between the groups. Uetake et al. (2018) investigated the values of seven factors (number of calves, lactation period, milk yield, body weight, body condition score, month of hair removal, and hair color) on cortisol levels of lactating dairy cows. They found that seasonal variation should be considered in a field study when cortisol levels in lactating cows are used as an indicator of a cow's endocrine response to stress.

Changes in cortisol and dehydroepiandrosterone (DHEA) concentrations in the hair of Italian Simmental dairy cows were studied by Peric et al. (2017). The animals were kept in tethered housing and grazed on high mountain pastures. It was found that the cortisol/DHEA ratio measured in the hair of dairy cows can be used to assess allostatic load in animals that were tethered or kept on a cow pasture. Parra et al. (2018) investigated the potential utility of hair steroid determination. For this purpose, the relationships between cortisol, progesterone, cows' physiological data, and their production and milk quality were studied. In the experiment, hair steroid concentrations were found to be positively correlated to cortisol and progesterone. Nejad et al. (2019) conducted a study to determine serum cortisol and cortisol concentrations in hair at different body sites of lactating Holstein cows and heifers in the thermal comfort zone. There were no significant differences in hair cortisol concentrations between different sampling sites in cows and heifers. Endo et al. (2017) studied the productive and reproductive traits of Brown Swiss crossbred cows and compared them with the traits of Holstein cows housed in the same barn. In addition, hair cortisol levels were analyzed to evaluate the degree of stress the cows were exposed to during dry and milking periods. It was found that hair cortisol levels increased significantly in Holstein cows during the 60 to 90 days after parturition compared with the dry period and were higher than in Brown Swiss cows during the same period. These results suggest that Brown Swiss crosses have less metabolic stress during early lactation, which may lead to earlier recovery of reproductive function.

\section{Analysis of fecal samples for cortisol content}

Jurkovich et al. (2017) analyzed cortisol metabolites (Table 3). Faecal tissue samples were collected from the cows and it was found that the concentration of fecal corticosteroids was significantly higher during milking in the parlor, both in the morning and evening than during robotic milking. This confirms that milking in the parlor causes more stress to dairy cows than robotic milking.

\section{Determination of glucose tolerance and insulin sensitivity}

Burdick-Sanchez et al. (2016) investigated whether cattle temperament affects the metabolic response to glucose tolerance and insulin sensitivity. On the 7 th day of the experiment, bulls received $0.5 \mathrm{~mL} / \mathrm{kg}$ of a $50 \%$ dextrose solution intravenously followed by an insulin bolus (a dose of insulin administered before or during a meal to cover glucose). Mean serum cortisol concentrations were found to be higher in temperamental bulls than in calm bulls after administration of the dextrose bolus (temperament score estimated at weaning). After administration of the insulin bolus, temperamental bulls decreased rectal temperature more than calm bulls. Curley et al. (2008) examined temperament ratings using multiple techniques and multiple observations and evaluated the relationship of temperament ratings to serum cortisol concentrations. They found that serum cortisol concentrations were affected by time and temperament (nervous temperament) within 6 hours of the experiment and that Brahmin heifers showed an increased response to grooming stress. Due to the initial handling stress, the pituitary and adrenal responses were greater in temperamental heifers than in calm heifers.

\section{OTHER EFFECTS ON TEMPERAMENT OR RELATIONSHIPS}

\section{Breed}

Temperamental differences may be a breed trait. Fordyce et al. (1988) found a statistically significant difference in temperament between animals of Brahman crosses and the Shorthorn breed. Horned calves appeared to have calmer temperaments than hornless calves. Lanier et al. (2000) found that Holstein cows were significantly more sensitive to sound and touch than beef cattle breeds. Gauly et al. (2001a) outlined characteristic differences in test behavior (combination of separation and retention test) between breeds (Simmental breed and German Angus); animals of the German Angus breed were characteristically calmer. Hoppe et al. (2010) showed that Simmental and Charolais animals were more nervous or that Angus and Hereford breeds had calmer temperaments. Mazurek et al. (2011) studied the behavior of crossbred (purebred Simmental and Simmental $\times$ Black and White) heifers, and Endo et al. (2017) studied Holstein and Brown Swiss crossbred cows. It was found that crossbreds exhibited stable behavior and had less metabolic stress in early lactation, while purebred heifers showed more metabolic stress and higher cortisol levels. Kosztolányiné et al. (2018) reported that calves of the Charolais breed were more nervous compared to calves of the French beef breed Aubrac.

\section{Experience and fear}

During rearing, animals meet environments where they have both positive and negative experiences that influence the formation of their temperament. Temperament is also influenced in part by genetic influences such as the breed of cattle. In addition to genetic traits, temperament is also influenced by experiences. Grandin (1997) stated that genetic traits and past experiences influence how animals respond to a caregiver. A similar result was found by Petherick et 
al. (2009), in which it was found that treating animals well reduces their fear of humans. By contrast, animals that have had a negative experience with rough treatment show greater fear of humans (Passille and Rushen, 2005) and learn to avoid unwanted caregivers (Munksgaard et al., 2001).

\section{Sex and age}

Some studies have shown that temperament is affected by age and sex. The results of others, however, do not entirely support this assertion. It was found that male cattle have more favorable temperaments and are easier to handle (Voisinet et al., 1997, Gauly et al., 2001b, Hoppe et al., 2010). By contrast, Burrow (1997) found that sex had no effect on animal movement speed at weaning but did affect movement speed at 18 months of age. A short flight time means a quicker exit from the crush and indicates that the animal has an undesirable temperament. Moreover, Fordyce et al. (1988) determined no effect of age on the temperament of cows and bulls during herd management; older cattle had less sensitive temperament than younger cattle (Lanier et al., 2000). In addition, cattle became "relatively mild" (1-mild, 4-nervous) with age, although the classification of temperament scores of individual animals did not change significantly during their lifetime (Sato, 1981).

\section{Animal exterior and temperament}

For centuries, the exterior of animals has played an important role in the breeding and selection of cattle. Based on the fact that only healthy and resistant animals can perform at a high level, a number of external animal characteristics have been identified as enabling systematic breeding of animals. The characteristics of linear evaluation describe the biological extremes of the animals, whereby the principle of the evaluation is "description" rather than "evaluation". This is based on the fact that objective knowledge of characteristics should be based on ex post evaluation, which requires a precise definition of characteristics. Linear traits must be clearly defined and independent (Fleckscore - linear score of Fleckvieh, 2014). Moreover, the relationship of leg and udder traits with animal longevity is well known. Larroque et al. (1999) estimated the negative genetic correlation between postpartum rest and temperament $\left(\mathrm{r}_{\mathrm{G}}=-0.26\right)$ and showed, surprisingly, that nervous cows had somewhat better results in artificial insemination. Temperament had a low genetic correlation $\left(\mathrm{r}_{\mathrm{G}}=0.23\right)$ with functional longevity, suggesting that the nervous cow had a higher risk of culling. A high genetic correlation between temperament and unproblematic milking $\left(r_{G}=0.56\right)$ has been reported (Berry et al., 2004). It was found that increased blood cortisol levels were accompanied by a negative genetic correlation between temperament and somatic cell count (Hemsworth et al., 1989).

\section{Influence of temperament on production and reproduction traits}

Temperament has a significant effect on safety at work, animal productivity, health, and animal welfare. The results from research on the influence of temperament on production traits are not uniform. Some authors have reported the influence of temperament on production, while others have not found these relationships. The effect of temperament on production results was not found/confirmed in all studies. Voisinet et al. (1997) studied the influence of temperament on the daily gain of calves. They found a significant effect of temperament on the average daily gain in crossbreeds of Bos indicus cross and cattle Bos taurus.

Animals of Brahman breeding had a higher average temperament score and were more excitable than other animals. Studies have shown that quieter and calmer cattle reach higher daily gains than cattle that are regularly irritated during routine handling (Burrow, 1997; Sant'Anna et al., 2018). The aim of an early study was to investigate whether inbreeding with Zebu breed negatively affected production and reproductive, traits and temperament. Inbreeding increased meat toughness but had no significant effect on temperament (Burrow, 1997). Sant'Anna et al. (2018) studied the genetic relationship between temperament, growth, and meat quality in Nellore cattle. The results showed that cattle with a nervous temperament had lower daily gains, feed conversion, fitness, and carcass characteristics.

Black et al. (2013) studied the relationships between feed intake and temperament in growing heifers and then repeated the observations with the same animals three years later when cows were in the third lactation. Authors reported no relationship of feed intake with animal differences in temperament.

Fear of dairy cows negatively affected their milk production (Hemsworth et al., 2003). Petherick et al. (2009) investigated 144 bulls that experienced one of three human handling experiences six times (over a one-year period) during the 12 -month post-weaning grazing period. Bulls were exposed to good handling (neutral or positive experience with the animal), poor handling (negative experience with the animal), or minimal handling (the experiment was designed so that cattle had minimal experience with handling and management on pasture, as is common in extensive production). It was found that good human behavior reduced animal fear of humans.

Carvalhal et al. (2017) showed that in the milking parlor had more reactive cows, lower milk yield with lower fat content, and higher somatic cell count. Temperament had a significant effect on milk yield in the first lactation, daily milk yield in the first lactation, and daily milk yield in live production. In cows with a calm temperament, milk yield in the first lactation was $621 \mathrm{~kg}$ higher than in cows with a "normal" temperament and $329 \mathrm{~kg}$ higher than in cows with a nervous (aggressive) temperament. Neja et al. (2015) and Bharadawaj et al. (2007) found that milk yield of Murrah buffalo was higher in calm $(2,120 \pm 27 \mathrm{~kg})$ than in nervous cows $(1,829 \pm 49 \mathrm{~kg})$ and lowest in aggressive animals $(1,743$ $\pm 147 \mathrm{~kg})$. 
Kalińska and Slósarz (2016) studied the influence of cow temperament and milking speed, their lifelong milk production, and the causes of cow culling. They found that calm animals had a higher lifetime milk yield and produced more fat and protein than excitable or aggressive cows. The main cause of culling was fertility and reproductive disorders (average of $41.2 \%$ ), though $15.3 \%$ of the cows were culled due to udder diseases. The results showed a significant effect of temperament and milking flow on cow longevity and lifetime performance.

Marçal-Pedroza et al. (2020) studied the relationship between temperament traits and milk yield. They found that milk yield was negatively associated with the number of kicking at milking and positively associated with rumination (chewing). Orbán et al. (2011) conducted an experiment to investigate the association between temperament, milk yield, and somatic cell count. The study confirmed there was no significant relationship between daily milk production and cow temperament. Nevertheless, milk somatic cell count showed a moderate positive relationship with temperament scores in Jersey and Friesian Holstein cows. Calmer cows had lower somatic cell counts than more temperamental cows. This was also confirmed by Gergovska et al. (2014), who found that milk from cows with a nervous temperament had a significantly higher somatic cell count in comparison to calm cows. However, the relationship between the temperament score and somatic cell count was not linear, as even very calm cows had relatively high somatic cell counts in milk.

Some authors have investigated whether introducing heifers to the milking parlor before calving can alter their behavior towards humans and their physiological responses later in the parlor when entering lactation (Sutherland and Huddart, 2012a). Heifers were introduced to milking by walking them through the milking parlor. The results showed that heifers in the test group, habituated to the milking parlor, were under less stress during milking in the first week of lactation than the control group. Heifers that had not been accustomed to the milking parlor beforehand had a lower milk yield, which they linked to the physiological reactions of the heifers. Hedlund and Løvlie (2015) reported that cows stepping more during milking or spending more time facing the herd during social isolation produced less milk in their first lactation.

Nervous temperament negatively affected pregnancy performance in Bos indicus cows undergoing estrus synchronization (Cooke et al., 2011, 2019). This resulted in fewer births and weaned calves than animals with calmer temperaments. Cziszter et al. (2016) evaluated temperament in relation to physiological and productive responses and the effects of temperament on pregnancy over time in Simmental cows. Characteristic phenotypic correlations were found between temperament and cow body weight $(r=-0.19)$, milk yield $(\mathrm{r}=-0.19)$, fat yield $(\mathrm{r}=-0.14)$, protein yield $(\mathrm{r}=$ $-0.18)$, and milking speed $(r=-0.18)$. Obviously, selection for calmer temperament could increase milk yield, fat, and protein content in milk as well as shorten the period between calvings and improve milk flow.

\section{Temperament and breeding programs}

In Australia and the Nordic countries, milking temperament is already integrated into selection indexes. Most countries use a scale to assess temperament from 1 to 5 (nervous to calm). The exceptions are Norway, which uses grades from 1 to 3, and United Kingdom, where the term "ease of milking" is used. Sewalem et al. (2010) reported that national genetic assessments of milking speed and milking behavior have been conducted in Canada since 1996 and 2001, respectively. Wethal and Heringstad (2019) identified promising genetic parameters for new traits describing milking efficiency and milking temperament in automatic milking systems in an experiment. Research has shown that high repeatability for continuous traits suggests that only a few observations during milking are required to obtain meaningful information for breeding purposes.

\section{CONCLUSIONS}

Researchers are seeking a reliable tool to determine and evaluate temperament; in current review, different approaches are being used to assess temperament. A qualitative scale based on the observer's assessment usually defines subjective methods of assessing temperament traits. In subjective temperament assessments, it is difficult to determine which methods are better or worse. These findings are further supported through the use of objective methods based on various tests and/or stress markers in feces, hair, saliva, and blood. The use of molecular methods allows us to gain insights into understanding the genetic control of temperament. In some countries, temperament at the milking stage is already included in a selection index in breeding programs.

\section{REFERENCES}

1. Benhajali, H., Boivin, X., Sapa, J., Pellegrini, P., Boulesteix, P., Lajudie, P., \& Phocas, F. (2010). Assessment of different on-farm measures of beef cattle temperament for use in genetic evaluation. Journal of Animal Science, 88(11), 3529-3537. doi:10.2527/jas.2010-3132

2. Berry, D. P., Buckley, F., Dillon, P., Evans, R. D., \& Veerkamp, R. F. (2004). Genetic relationships among linear type traits, milk yield, body weight, fertility and somatic cell count in primiparous dairy cows. Irish Journal of Agricultural and Food Research, 43, 161-176.

3. Bharadwaj, A., Dixit, V. B., Seth, R. K., \& Khanna, S. (2007). Association of breed characteristics with milk production in Murrah buffaloes. Indian Journal of Animal Sciences, 77, 1011-1016.

4. Bharti, P., \& Kamboj, M., (2019). Effect of habituation to milking and natural suckling on milking behavior and milk production characteristics in primiparous Sahiwal Cows. Indian Journal of Dairy Science, 72(3), 312-317. doi: 10.33785/IJDS.2019.v72i03.012

5. Black, T. E., Bischoff, K. M., Mercadante, V. R. G., Marquezini, G. H. L., Di Lorenzo, N., Chase, C. C., 
Coleman, S. W., Maddock, T. D., \& Lamb, G. C. (2013). Relationships among performance, residual feed intake, and temperament assessed in growing beef heifers and subsequently as 3-year-old, lactating beef cows. Journal of Animal Science, 91(5), 2254-2263. doi:10.2527/ jas.2012-5242

6. Boissy, A., \& Bouissou, M. (1995). Assessment of individual differences in behavioural reaction of heifers exposed to various fear-eliciting situations. Applied Animal Behaviour Science, 46, 17-31. doi: 10.1016/01681591(95)00633-8

7. Braun, U., Michel, N., Baumgartner, M., Hässig, M., \& Binz, T. (2017). Cortisol concentration of regrown hair and hair from a previously unshorn area in dairy cows. Research in Veterinary Science, 114, 412-415. doi:10.1016/j.rvsc.2017.07.005

8. Braun, U., Wiest, A., Lutz, T. A., Riond, B., Hilbe, M., Baumgartner, M., \& Binz, T. (2019). Hair cortisol concentration in veal calves reared under two different welfare production labels. Research in Veterinary Science, 123, 286-292. doi: 10.1016/j.rvsc.2019.01.027

9. Breuer, K., Hemsworth, P., Barnett, J., Matthews, L., \& Coleman, G. (2000). Behavioural response to humans and the productivity of commercial dairy cows. Applied Animal Behaviour Science, 66, 273-288. doi:10.1016/ s0168-1591(99)00097-0

10. Brouček, J., Uhrinčat', M., Tančin, V., Hanus, A., Tongel, P., Botto, L., \& Božik, I., (2013). Performance and behaviour at milking after relocation and housing change of dairy cows. Czech Journal of Animal Science, 58(9), 389-395. doi:10.17221/6938-CJAS

11. Burdick Sanches, N. C., Carroll, J. A., Broadway, P. R., Hughes, H. D., Roberts, S. L., Richeson, J. T., Schmidt, T. B., \& Vann, R. C. (2016). Cattle temperament influences metabolism: metabolic response to glucose tolerance and insulin sensitivity tests in beef steers. Domestic Animal Endocrinology, 56, 85-95. doi: 10.1016/j. rvsc.2019.01.027

12. Burnett, T. A., Madureira, A. M., Silper, B. F., Nadalin, A., Tahmasbi, A., Veira, D. M., \& Cerri, R. L. (2014). Short communication: Factors affecting hair cortisol concentrations in lactating dairy cows. Journal of Dairy Science, 97(12), 7685-7690. doi:10.3168/jds.2014-8444

13. Burrow, H. M. (1997). Measurement of temperament and their relationship with performance traits of beef cattle. Animal Breeding Abstract, 65, 477-495. doi: 10.4141/ cjas2010-041

14. Cafe, L. M., Robinson, D. L., Ferguson, D. M., McIntyre, B. L., Geesink, G. H., \& Greenwood, P. L. (2011). Cattle temperament: persistence of assessments and associations with productivity, efficiency, carcass and meat quality traits. Journal of Animal Science, 89(5), 1452-1465. doi:10.2527/jas.2010-3304

15. Carlström, C., Strandberg, E., Petterson, G., Johansson, K., Stälhammar, H., \& Philipsson, J. (2016). Genetic associations of teat cup attachment failures, incomplete milkings, and handling time in automatic milking systems with milkability, temperament, and udder conformation. Acta Agriculturae Scandinavica, Section A - Animal Science, 66, 75-83. doi:10.1080/09064702.
2016.1260153

16. Carvalhal, M. V. d. L., Sant'Anna, A. C., Páscoa, A. G., Jung, J., \& Paranhos da Costa, M. J. R. (2017). The relationship between water buffalo cow temperament and milk yield and quality traits. Livestock Science, 198, 109-114. doi:10.1016/j.livsci.2017.02.016

17. Cooke, R., Bohnert, D., Meneghetti, M., Losi, T., \& Vasconcelos, J. (2011). Effects of temperament on pregnancy rates to fixed-timed AI in Bos indicus beef cows. Livestock Science, 42, 108-113. doi:10.1016/j. livsci.2011.06.024

18. Cooke, R., Morie, 1., Cappellozza, B., Miranda, V., Batista, L., Colombo, E., Ferreira, V. S. M., Miranda, M. F., Marques, R. S., \& .Vasconcelos, J. (2019). Effects of temperament on growth, plasma cortisol concentrations and puberty attainment in Nelore beef heifers. Animal, 13, 1208-1213. doi: 10.1017/S1751731118002628

19. Curley, K. O., Jr., Neuendorff, D. A., Lewis, A. W., Cleere, J. J., Welsh, T. H., Jr., \& Randel, R. D. (2008). Functional characteristics of the bovine hypothalamic-pituitaryadrenal axis vary with temperament. Hormones and Behavior, 53(1), 20-27. doi:10.1016/j.yhbeh.2007.08.005

20. Cziszter, L., Gavojdian, D., Neamt, R., Neciu, F., Kusza, S., \& Ilie, D. (2016). Effects of temperament on production and reproductive performances in Simmental dualpurpose cows. Journal of Veterinary Behavior, 15, 50-55. doi: 10.1016/j.jveb.2016.08.070

21. Dickson, D., Johnson, L., \& Wieckert, D. (1970). Social dominance and temperament of Holstein cow. Journal of Dairy Science, 53(7), 904-907. doi:10.3168/jds.S00220302(70)86316-0

22. Dutt, T., Sinha, R. R. K., Singh, M., Bharti, P. K., Patel, B. H. M., \& Gaur, K. G. (2016). Effect of temperament on production, reproduction and milking behaviour of Vrindavani cows in an organized herd. Indian Journal of Animal Sciences, 86, 950-952. doi:

23. Ebinghaus, A., Ivemeyer, S., \& Knierim, U. (2018). Human and farm influences on dairy cows responsiveness towards humans - a cross-sectional study. PLoS One, 13(12), e0209817. doi:10.1371/journal.pone.0209817

24. Ebinghaus, A., Ivemeyer, S., Rupp, J., \& Knierim, U. (2016). Identification and development of measures suitable as potential breeding traits regarding dairy cows reactivity towards human. Applied Animal Behaviour Science, 185, 30-38. doi:10.1016/j.applanim.2016.09.010

25. Endo, N., Kuroki, R., \& Tanaka, T. (2017). Comparison of productive and reproductive performance and hair cortisol levels between Brown Swiss cross-bred and Holstein cows housed in the same barn. Animal Science Journal, 88(10), 1506-1512. doi:10.1111/asj.12828

26. Fahim, A., Kamboj, M., Bhakat, M., Mohanty, T., \& Gupta, R. (2018). Preference of side and standing in relationship with milking characteristic and temperament score of crossbred. Turkish Journal of Veterinary and Animal Sciences, 42, 49-54. doi:10.3906/vet-1705-1

27. Ferguson, D., \& Warner, R. (2008). Have we underestimated the impact of pre-slaughter stress on meat quality in ruminants. Meat Science, 80, 12-19. doi:10.1016/j.meatsci.2008.05.004

28. Fordyce, G., Dodt, R., \& Wythes, J. (1988). Cattle 
temperaments in extensive beef herds in northern Queensland. 1. Factors affecting temperament. Australian Journal of Experimental Agriculture, 28(6), 683-687. doi:10.1071/EA9880683

29. Fordyce, G., Goddard, M. E., \& Seifert, G. W. (1982). The measurement of temperament in cattle and the effect of experience and senotype. Proceedings of the Australian Society of Animal Production, 14, 329-332.

30. Foris, B., Zebunke, M., Langbein, J., \& Melzer, N. (2018). Evaluating the temporal and situational consistency of personality traits in adult dairy cattle. PLoS One, 13(10), e0204619. doi:10.1371/journal.pone.0204619

31. Gauly, M., Mathiak, H., Hoffmann, K., Kraus, M., \& Erhardt, G. (2001a). Estimating genetic variability in temperamental traits in German Angus and Simmental cattle. Applied Animal Behaviour Science, 74(2), 109-119. doi:10.1016/S0168-1591(01)00151-4

32. Gauly, M., Mathiak, H., Kraus, M., Hoffman, K., \& Erhard, G. (2001b). Rasse und Geschlechtsunterschiede im Temperament von kälbern in Mutterkuhhaltung. Deutsche tierärztliche Wochenschrift, 108, 206-210.

33. Gergovska, Z., Marinov, I., Penev, T., \& Angelova, T. (2014). Effect of milking temperament on productive traits and SCC in Black-and-White cows. International Journal of Current Microbiology and Applied Sciences, 3(8), 1-11.

34. Gibbons, J. M. (2009). The Effect of selecting for "robustness" on temperament in dairy cows. ERA The University of Edinburgh.

35. Gibbons, J., Lawrence, A., \& Haskell, M. (2009). Consistency of aggressive feeding behaviour in dairy cows. Applied Animal Behaviour Science, 121(1), 1-7. doi:doi.org/10.1016/j.applanim.2009.08.002.

36. Glenske, K., Prinzenberg, E. M., Brandt, H., Gauly, M., \& Erhardt, G. (2010). A chromosome-wide QTL study on BTA29 affecting temperament traits in German Angus beef cattle and mapping of DRD4. Anim. 5:2 195 - 197. doi:10.1017/S1751731110001801

37. Grandin, T. (1989). Behavioral principles of livestock handling. Professional Animal Scientist, 5(2), 1-11. doi:10.15232/S1080-7446(15)32304-4

38. Grandin, T. (1997). Assessment of stress during handling and transport. Journal of Animal science, 75(1), 249-257. doi:10.2527/1997.751249x

39. Graunke, K. L., Nürnberg, G., Repsilber, D., Puppe, B., \& Langbein, J. (2013). Describing temperament in an ungulate: A multidimensional approach. PLoS ONE, 8(9), e74579. doi:0.1371/journal.pone.0074579

40. Gutiérrez-Gil, B., Ball, N., Burton, D., Haskell, M., Williams, J. L., \& Wiener, P. (2008). Identification of quantitative trait loci affecting cattle temperament. Journal of Heredity, 99(6), 629-638. doi:10.1093/jhered/ esn060

41. Haskell, M. J., Simm, G., \& Turner, S. P. (2014). Genetic selection for temperament traits in dairy and beef cattle. Frontiers in Genetics, 5(368), 1-18. doi:10.3389/ fgene. 2014.00368

42. Head, H. H., Kull, R. C, Campos, Jr. M. S., Bachman, K. C., Wilcox, C. J., Cline, L. L., \& Hayen, M. J. (1993). Milk yield, milk composition, and behavior of Holstein cows in response to jet aircraft noise before milking. Journal of Dairy Science, 76, 1558-1567. doi:10.3168/jds.S00220302(93)77489-5

43. Hedlund, L., \& Løvlie, H. (2015). Personality and production: Nervous cows produce less milk. Journal of Dairy Science, 98, 5819-5828. doi:doi.org/10.3168/ jds.2014-8667

44. Hemsworth, P. H. (2003). Human-animal interactions in livestock production. Applied Animal Behavior Science, 81, 185-198. doi: 10.1016/S0168-1591(02)00280-0

45. Hemsworth, P., Barnett, J., Tilbrook, A., \& Hansen, C. (1989). The effects of handling by humans at calving and during milking on the behaviour and milk cortisol concentrations of primiparous dairy cows. Applied Animal Behaviour Science, 22(3-4), 313-326. doi:10.1016/0168-1591(89)90026-9

46. Hoppe, S., Brandt, H. R., Konig, S., Erhardt, G., \& Gauly, M. (2010). Temperament traits of beef calves measured under field conditions and their relationships to performance. Journal of Animal Science, 88(6), 19821989. doi:10.2527/jas.2008-1557

47. Jurkovich, V., Kezer, F. L., Ruff, F., Bakony, M., Kulcsar, M., \& Kovacs, L. (2017). Heart rate, heart rate variability, faecal glucocorticoid metabolites and avoidance response of dairy cows before and after changeover to an automatic milking system. Acta Veterinaria Hungarica, 65(2), 301-313. doi:10.1556/004.2017.029

48. Kadel, M. J., Johnston, D. J., Burrow, H. M., Graser, H.-U., \& Ferguson, D. M. (2006). Genetics of flight time and other measures of temperament and their value as selection criteria for improving meat quality traits in tropically adapted breeds of beef cattle. Australian Journal of Agricultural Research, 57(9), 1029-1035. doi:10.1071/ar05082

49. Kalińska, A., \& Slósarz, J. (2016). Influence of cow temperament and milking speed on herd life, lifetime milk yield and reasons of cow culling. Annals of Warsaw University of Life Sciences, 55, 177-186.

50. Kilgour, B. R. (1975). The open-field test as an assessment of the temperament of dairy cows. Animal Behaviour, 23, 615-624. doi:10.1016/0003-3472(75)90139-6

51. Kilgour, R., Melville, G., \& Greenwoodac, P. (2006). Individual differences in the reaction of beef cattle to situations involving social isolation, close proximity of humans, restraint and novelty. Applied Animal Behaviour Science, 99(1-2), 21-40. doi:10.1016/j. applanim.2005.09.012

52. Kosztolányiné, S., Vertséné, Z., \& Tőzsér, J. (2018). New results on temperament of Aubrac and Charolais cattle kept in a Hungarian herd. Animal Welfare, Ethology and Housing Systems, 14(2), 63-77.

53. Lanier, J. L., Grandin, T., Green, R. D., Avery, D., \& McGee, K. (2000). The relationship between reaction to sudden, intermittent movements and sounds and temperament. Journal of Animal Science, 78(6), 14671474. doi:10.2527/2000.7861467x

54. Larroque, H., Rupp, R., Moureaux, S., Boichard, D., \& Ducrocq, V. (1999). Genetic parameters for type and functional traits in the French Holstein breed. Interbull Bulletin, 23, 169-179. 
55. MacKay, J. R., Turner, S. P., Hyslop, J., Deag, J. M., \& Haskell, M. J. (2013). Short-term temperament tests in beef cattle relate to long-term measures of behavior recorded in the home pen. Journal of Animal Science, 91(10), 4917-4924. doi:10.2527/jas.2012-5473

56. Magolski, J., Berg, E., Hall, N., Anderson, V., Keller, W., Jeske, T., \& Maddock Carlin, K. (2013). Evaluation of feedlot cattle working chute behavior relative to temperament, tenderness, and postmortem proteolysis. Meat Science, 95, 92-97. doi:10.1016/j. meatsci.2013.04.001

57. Marçal-Pedroza, M. G., Campos, M. M., Pereira, L. G. R., Machado, F. S., Tomich, T. R., Paranhos da Costa, M. J. R., \& Sant'Anna, A. C. (2020). Consistency of temperament traits and their relationships with milk yield in lactating primiparous F1 Holstein - Gyr cows. Applied Animal Behaviour Science, 222, 1-8. doi:10.1016/j. applanim.2019.104881

58. Mazurek, M., McGee, M., Crowe, M. A., Prendiville, D. J., Boivin, X., \& Earley, B. (2011). Consistency and stability of behavioural fear responses of heifers to different feareliciting situations involving humans. Applied Animal Behaviour Science, 131(1-2), 21-28. doi:10.1016/j. applanim.2011.01.004

59. Müller, R., \& Keyserlingk, M. (2006). Consistency of flight speed and its correlation to productivity and to personality in Bos Taurus beef cattle. Applied Animal Behaviour Science, 99(3-4), 193-204. doi:10.1016/j. applanim.2005.05.012

60. Munksgaard, L., DePassille, A., Rushen, J., Herskin, M., \& Kristensen, A. (2001). Dairy cows, fear of people: social learning, milk yield and behavior at milking. Applied Animal Behaviour Science, 73(1), 15-26. doi:10.1016/ S0168-1591(01)00119-8

61. Neja, W., Sawa, A., Jankowska, M., Bogucki, M., \& Czopek, S. (2015). Effect of temperament of dairy cows on lifetime production effiency. Archives Animal Breeding, 58, 193-197. doi:10.5194/aab-58-193-2015

62. Nejad, J. C, Lee, B.-H., Kim, J.-J., Kim, B.-W., Chemere, B., Park, K.-H., \& Sung, K.-I. (2019). Comparing hair cortisol concentrations from various body sites and serum cortisol in Holstein lactating cows and heifers during thermal comfort zone. Journal of Veterinary Behavior, 30, 92-95. doi:10.1016/j.jveb.2018.12.007

63. Orbán, M., Gaál, K. K., Pajor, F., Szentléleki, A., Póti, P., Tőzsér, J., \& Gulyás, L. (2011). Effect of temperament of Jersey and Holstein Friesian cows on milk production traits and somatic cell count. Archives Animal Breeding, 54(6), 594-599. doi:10.5194/aab-54-594-2011

64. Parra, O. T., Carbajal, A., Monclús, L., Manteca, X., \& Lopez-Bejar. M. (2018). Hair cortisol and progesterone detection in dairy cattle: interrelation with physiological status and milk production. Domestic Animal Endocrinology, 64, 1-8. doi:10.1016/j. domaniend.2018.02.001

65. Passille, A., \& Rushen, J. (2005). Can we measure human - animal interactions in on - farm animal welfare assessment? Some unresolved issues. Applied Animal Behaviour Science, 92(3), 193-209. doi: 10.1016/j. applanim.2005.05.006
66. Peric, T., Corazzin, M., Romanzin, A., Bovolenta, S., Prandi, A., Montillo, M., \& Comin, A. (2017). Cortisol and DHEA concentrations in the hair of dairy cows managed indoor or on pasture. Livestock Science, 202, 39-43. doi:10.1016/j.livsci.2017.05.020

67. Petherick, J. C., Doogan, J. V., Holroyd, R., \& Olsson, P. (2009). Quality of handling and holding yard environment, and beef cattle temperament: 1 . Relationships with flight speed and fear of humans. Applied Animal Behaviour Science, 120(1-2), 18-27. doi:10.1016/j.applanim.2009.05.008. doi:10.1016/j. applanim.2009.05.008

68. Petherick, J. C., Holroyd, R. G., Doogan, V. J., \& Venus, B. (2002). Productivity, carcass and meat quality of lot-fed Bos indicus cross steers grouped according to temperament. Australian Journal of Experimental Agriculture, 42(4), 389-398. doi:10.1071/EA01084

69. Probst, J., Neff, A., \& Leiber, F. (2012). Gentle touching in early life reduces avoidance distance and slaughter stress in beef cattle. Applied Animal Behaviour Science, 139(1-2), 42-49. doi:10.1016/j.applanim.2012.03.002. doi:10.1016/j.applanim.2012.03.002

70. Reenen van, C.G, Werf,J.T. N., O'Connell, N.E., Heutinck, L. F. M., Spoolder, H. A. M., Jones, R. B., Koolhaas, J. M., \& Blokhuise, H. J. (2013). Behavioural and physiological responses of heifer calves to acute stressors: Long-term consistency and relationship with adult reactivity to milking. Applied Animal Behaviour Science, 147(1-2), 55-68. doi:10.1016/j.applanim.2013.04.020

71. Reenen van, C. G., van Werf, J. T. N., Bruckmaier, R. M., Hopster, H., Engel, B., Noordhuizen, J. P. T. M., \& Blockhuis, H. J. (2002). Individual differences in behavioral and physiological responiveness of primiparous dairy cows to machine milking. Journal of Dairy Science, 85(10), 2551-2561. doi: 10.3168/jds. S0022-0302(02)74338-5

72. Rousing, T., Bonde, M., Badsberg, J., \& Sorensen, J. (2004). Stepping and kicking behavior during milking in relation to response in human-animal interaction test and clinical health in loose housed dairy cows. Livestock Production Science, 88(1-2), 1-8. doi:10.1016/j.livprodsci.2003.12.001. doi: 10.1016/j. livprodsci.2003.12.001

73. Sant'Anna, A. C., Paranhos da Costa, M. J. R., Baldi, F., \& Albuquerque, L. G. (2013). Genetic variability for temperament indicators of Nellore cattle. Journal of Animal Science, 91(8), 3532-3537. doi:10.2527/jas.20125979

74. Sato, S. (1981). Factors associated with temperament of beef cattle. Japanese Journal of Zootechnical Science, 52(8), 595-605.

75. Schwartzkopf-Genswein, K. S., Shah, M. A., Church, J. S., Haley, D. B., Janzen, K., Truong, G., Atkins R. P., \& Crowe, T. G. (2012). A comparison of commonly used and novel electronic techniques for evaluating cattle temperament. Canadian Journal of Animal Science, 92, 21-31. doi:doi.org/10.4141/cjas2011-040

76. Schwartzkopf-Genswein, K. S., Stookey, J. M., \& Welford, R. (1997). Behavior of cattle during hot-iron and freeze branding and the effects on subsequent 
handling ease. Journal of Animal Science, 75(8), 20642072. doi:10.2527/1997.7582064x

77. Sebastian, T., Watts, J., Stookey, J., Buchanan, F., \& Waldner, C. (2011). Temperament in beef cattle: Methods of measurement and their relationship to production. Canadian Journal of Animal Science, 91(4), 557-565. doi:10.4141/cjas2010-041

78. Sewalem, A., Kistemaker, G. J., \& van Doormaal, B. J. (2002). Bayesian inferences for milking temperament in canadian holsteins. 7th World Congress on Genetics Applied to Livestock Production, 19-23.

79. Sewalem, A., Miglior, F., \& Kistemaker, G. (2011). Short communication: Genetic parameters of milking temperament and milking speed in Canadian Holsteins. Journal of Dairy Science, 94(1), 512-516. doi:10.3168/ jds.2010-3479

80. Shahin, M. (2018). The effects of positive human contact by tactile stimulation on dairy cows with different personalities. Applied Animal Behaviour Science, 204, 23-28. doi:10.1016/j.applanim.2018.04.004

81. Stephansen, R. S., Fogh, A., \& Norberg, E. (2018). Genetic parameters for handling and milking temperament in Danish first-parity Holstein cows. Journal of Dairy Science, 101(12), 11033-11039. doi:10.3168/jds.201814804

82. Sutherland, M., Rogers, A., \& Verkerk, G. (2012a). The effect of temperament and responsiveness towards humans on the behaviour, physiology and milk production of multi-parous dairy cows in a familiar and novel milking environment. Physiology \& Behavior, 107(3), 329-337. doi:10.1016/j.physbeh.2012.07.013

83. Sutherland, M., \& Huddart, F. (2012b). The effect of training first-lactation heifers to the milking parlor on the behavioral reactivity to humans and the physiological and behavioral responses to milking and productivity. Journal of Dairy Science, 95, 6983-6993. doi:10.3168/ jds.2011-5211

84. Uetake, K., Morita, S., Sakagami, N., Yamamoto, K., Hashimura, S., \& Tanaka, T. (2018). Factors that determine cortisol level in hair of lactating dairy cows. Journal of Animal Science, 96(3), 515. doi: 10.1093/jas/ sky404.1127

85. Vetters, M. D., Engle, T. E., Ahola, J. K., \& Grandin, T. (2013). Comparison of flight speed and exit score as measurements of temperament in beef cattle. Journal of Animal Science, 91(1), 374-381. doi:10.2527/jas.20125122

86. Voisinet, B. D., Grandin, T., Tatum, J. D., O'Connor, S. F., \& Struthers, J. J. (1997). Feedlot cattle with calm temperaments have higher average daily gains than cattle with excitable temperaments. Journal of Animal Science 75, 892-896. doi: 10.2527/1997.754892x

87. Waiblinger, S., Menke, C., \& Fölsch, D. (2003). Influences on the avoidance and approach behaviour of dairy cows towards humans on 35 farms. Applied Animal Behaviour Science, 84(1), 23-39. doi:10.1016/S01681591(03)00148-5. doi: 10.1016/S0168-1591(03)00148-5

88. Waynert, D. F., Stookey, J. M., Schwartzkopf-Genswein, K. S., Watts, J. M., \& Waltz, C. S. (1999). The response of beef cattle to noise during handling. Applied Animal
Behaviour Science, 62(1), 27-42. doi:10.1016/s01681591(98)00211-1

89. Wethal, K., \& Heringstad, B. (2019). Genetic analyses of novel temperament and milkability traits in Norwegian Red cattle based on data from automatic milking systems. Journal of Dairy Science, 102(9), 8221-8233. doi:10.3168/ jds.2019-16625

90. Windschnurer, I., Schmied, C., Boivin, X., \& Waiblinger, S. (2008). Reliability and inter-test relationship of tests for on-farm assessment of dairy cows' relationship to humans. Applied Animal Behaviour Science, 114(1-2), 37-53. doi:10.1016/j.applanim.2008.01.017

91. World Simmental-Fleckvieh Federation. (2014). Fleckscore - linear score of fleckvieh. https://www. fleckscore.com/ 


\section{Metode ocenjevanja temperamenta goveda in dejavniki, ki vplivajo nanj: pregledni članek}

\section{IZVLEČEK}

V živinoreji mora biti čreda sestavljena iz živali, ki so dobro prilagojene določenemu okolju, kar omogoča varno delovno okolje ter doseganje optimalnih proizvodnih in gospodarskih rezultatov. Živali se različno odzivajo na pozitivne in negativne dejavnike okolja. Odziv posameznika na nove razmere lahko vpliva na presnovo in različne fiziološke sisteme. Številne biokemične značilnosti se lahko uporabljajo kot označevalci za ocenjevanje temperamenta. Temperament lahko opredelimo tudi kot kombinacijo značilnosti ali lastnosti, ki tvorijo posameznikovo razlikovalno lastnost. V tem preglednem članku predstavljamo različne metode ocenjevanja temperamenta goveda, prvič, v okolju, ki ga žival pozna, kot sta hlev in molzišče, drugič, v neznanih posebnih prostorih ali arenah s posebno opremo, in tretjič, ob upoštevanju drugih možnih vplivov na izražanje temperamenta. Kot eden od pristopov k ocenjevanju temperamenta je bilo opisano tudi merjenje označevalcev stresa v slini, iztrebkih in dlaki $z$ neinvazivnimi metodami. Poznavanje temperamenta goveda nam omogoča varno delo, uvajanje ustrezno prilagojenih tehnologij reje in izboljšanje pogojev reje, kar posledično vpliva na boljše počutje živali.

Ključne besede: govedo, obnašanje, temperament, metode ocenjevanja 